\title{
Hexachlorocyclohexanes, Cyclodiene, Methoxychlor, and Heptachlor in Sediment of the Alvarado Lagoon System in Veracruz, Mexico
}

\author{
María del Refugio Castañeda-Chávez *, Fabiola Lango-Reynoso and \\ Gabycarmen Navarrete-Rodríguez \\ Tecnológico Nacional De México/Instituto Tecnológico de Boca del Río, \\ División de Estudios de Posgrado e Investigación, Boca del Río, Veracruz C.P. 94290, Mexico; \\ fabiolalango@itboca.edu.mx (F.L.-R.); gabycarmen.navarrete@colpos.mx (G.N.-R.) \\ * Correspondence: mariacastaneda@itboca.edu.mx; Tel.: +1-(229)-986-0189 (ext. 113) \\ Received: 15 November 2017; Accepted: 22 December 2017; Published: 5 January 2018
}

\begin{abstract}
Organochlorine pesticides are used in agricultural areas and health campaigns, which reach the coastal environment through rivers, drains, runoffs, and atmospheric transport. In aquatic environments, they are adsorbed by particles of organic matter, depositing themselves in sediments in the bottom of these bodies, in which benthic organisms of commercial interest for human consumption inhabit. The objective of this research was to evaluate the concentration of organochlorine pesticides in sediment from the Alvarado lagoon system in Veracruz, Mexico. In 20 out of 41 sampling sites analyzed, 11 banned organochlorine pesticides were identified, such as hexachlorocyclohexane $(\mathrm{HCH})$, lindane, aldrin, dieldrin, and endrin. The highest concentrations were as follows: aldrin: $46.05 \mathrm{ng} \mathrm{g}^{-1}$; $\beta-\mathrm{HCH}: 42.11 \mathrm{ng} \mathrm{g}^{-1} ; \alpha-\mathrm{HCH}: 38.44 \mathrm{ng} \mathrm{g}^{-1}$; gamma $\gamma-\mathrm{HCH}$ (lindane): $34.20 \mathrm{ng} \mathrm{g}^{-1}$; $\delta$-HCH: $31.61 \mathrm{ng} \mathrm{g}^{-1}$; methoxychlor: $29.40 \mathrm{ng} \mathrm{g}^{-1}$; heptachlor epoxide: $25.70 \mathrm{ng} \mathrm{g}^{-1}$; heptachlor: $24.11 \mathrm{ng} \mathrm{g}^{-1}$; dieldrin: $22.13 \mathrm{ng} \mathrm{g}^{-1}$; endrin: $21.23 \mathrm{ng} \mathrm{g}^{-1}$; endrin aldehyde: $12.40 \mathrm{ng} \mathrm{g}^{-1}$. Concentrations reported are prohibited in international standards. There is a strong need to further evaluate, with scientific studies, the level of concentration reported by impact of compounds widely used in agricultural livestock activities.
\end{abstract}

Keywords: agricultural activities; persistence; granulometry; obsolete pesticides

\section{Introduction}

Persistent organic compounds (POPs) are a chemical group that poses a high risk to public health and the environment; these compounds due to their transport capacity in the air or by runoffs reach areas far from where they were initially applied [1]. Because of their chemical characteristics, these organic molecules are classified as prohibited in the Stockholm Convention list. Additionally, compounds such as polychlorinated biphenyls (PCBs), dioxins, furans, and a variety of organochlorine pesticides including aldrin, dieldrin, DDT, endrin, chlordane, hexachlorobenzene, mirex, toxaphene, and heptachlor are prohibited [2,3].

Recent studies report the presence of these pesticides at high levels of concentration in soils, sediments, aquatic and terrestrial biota [4]. For its transport capacity, the presence of these compounds has been determined in various aquatic ecosystems of Mexico, becoming a risk to public health and the environment [5-8]. They have been found mainly among the coastal ecosystems located in the southeast region of the Gulf of Mexico. In addition, the presence of prohibited POPs as organochlorine pesticides: DDT, and their metabolites, endosulfan, lindane, among the main ones continues to be reported [9-13]. The authors of [14] indicated that the main routes of entry of organochlorine pesticides correspond to those used in agricultural areas, for its extensive use in the agricultural 
areas surrounding these lagoon systems, where the incorporation of these pesticides reach the coastal environment through rivers, drains, and runoffs and through atmospheric transport. Likewise, those that are used in health campaigns join them $[14,15]$. Once these compounds are found in aquatic environments, they are adsorbed by the organic matter particles in the water column. Here, several processes occur that cause the deposition of organochlorine compounds in the sediments of these water bodies, where they are in direct contact with benthic organisms that inhabit this zone and are of commercial interest for human consumption [16,17].

The sediment analysis in an aquatic ecosystem allows an integral estimation of its composition, since the sediment is the most stable matrix for the materials and substances dispersed in the water column. They are the main receptors of most of the contaminants deposited, due to their precipitation and accumulation capacity [17-19].

It must be considered, in coastal lagoons, that chemical compounds undergo transformations in addition to precipitation, such as dilution, flocculation, sedimentation, and degradation, before finally reaching the sea [20]. In relation to the above, the sediments to be exported with a certain load of pollutants to the coastal zone contribute to their acting as a secondary source of pollution in the marine environment. The processes of transformation can cause greater toxicity and increase its residence time in the water column and its toxicity in the benthic organisms that inhabit these ecosystems $[11,15,16,21]$.

Sediments, as a habitat of benthic biota, represent for these organisms a source of contamination, through removal mechanism for contaminants to and from the stream, and a vehicle for contaminant transport downstream [21].

An efficient way to evaluate the presence of hydrophobic compounds in aquatic bodies is the analysis of contaminants in sediments and aquatic benthic biota, which also have a low solubility in water, a high solubility in lipids, and a strong tendency to absorb organic material in soil and sediment $[17,21]$. Accordance to the above, it can be pointed out that chemical contaminants accumulating in benthic organisms that inhabit sediments can be transferred to higher trophic levels through the food chain and thus constitute elements of risk to public health [11,13]. Therefore, it is necessary to know the environmental quality of the sediments due to the effect it has on different trophic levels and on the transport of pollutants in the coastal zone. The objective of this work was to determine, in the sediment matrix of the Alvarado Veracruz lagoon system, the concentration of organochlorine pesticides: hexachlorocyclohexanes (HCHs), endrin, methoxychlor, and heptachlor.

\section{Materials and Methods}

\subsection{Study Area}

The Alvarado lagoon system is located in the southeast region of the state of Veracruz at coordinates $18^{\circ} 44^{\prime} 00^{\prime \prime}$ and $18^{\circ} 52^{\prime} 15^{\prime \prime}$ latitude north, $95^{\circ} 44^{\prime} 00^{\prime \prime}$ and $95^{\circ} 57^{\prime} 00^{\prime \prime}$ longitude west, located at $70 \mathrm{~km}$ from the southeast of the port of Veracruz with an elevation of $10 \mathrm{~m}$ above sea level [22-25]. This lagoon body has a total extension of approximately 6200 ha and a maximum width of $4.5 \mathrm{~m}$. The lagoon-estuarine system is made up of more than 100 brackish coastal lagoons and seasonally flooded areas. Among the main lagoon bodies are Alvarado, Camaronera, and Buen País, as well as internal lagoons such as Pajarillos, Popuyeca, and Embarcadero [26,27]. The main contributions of water to the system are the Papaloapan, Acula, Blanco, and Limón rivers; specifically, the first one contributes with the highest annual runoff with $2.1 \times 10^{3} \mathrm{~m}^{3}$ per year [22].

The average annual temperature is $26^{\circ} \mathrm{C}$, and the coldest monthly average is above $18{ }^{\circ} \mathrm{C}$. The average annual temperature is $22-26^{\circ} \mathrm{C}$, with a minimum value of $9.5^{\circ} \mathrm{C}$ and a maximum of $48^{\circ} \mathrm{C}$. The dry season is from January to May with an average monthly temperature of $39.5^{\circ} \mathrm{C}$. The rainy season is from June to October with a precipitation of $286-320 \mathrm{~mm}$ in the summer and an average monthly temperature of $29.5^{\circ} \mathrm{C}$. The north winds season is from November to January with an average monthly temperature of $21.8^{\circ} \mathrm{C}$. The precipitation of the driest months vary in a range of $0-60 \mathrm{~mm}$. 
Salinity reaches its maximum value during the dry season with $14.1 \%$ and a minimum in rainfall with $2.2 \%$, with a range of $0-24 \%$. Average depth in the system is estimated from 1 to $3 \mathrm{~m}$ approximately. The Alvarado lagoon is a water system with a high degree of turbidity (light and transparency of 0.5-1 $\mathrm{m}$ approximately), showing low transparency during the rainy season $[22,25,28]$.

\subsection{Collection and Treatment of Sediment Samples for Analysis}

For sample collection, 41 sampling sites were geo-referenced in the study area (Figure 1). The sediment collection was performed in triplicate during the dry season corresponding to April, May, and June. The samples collected were labeled, refrigerated and stored.

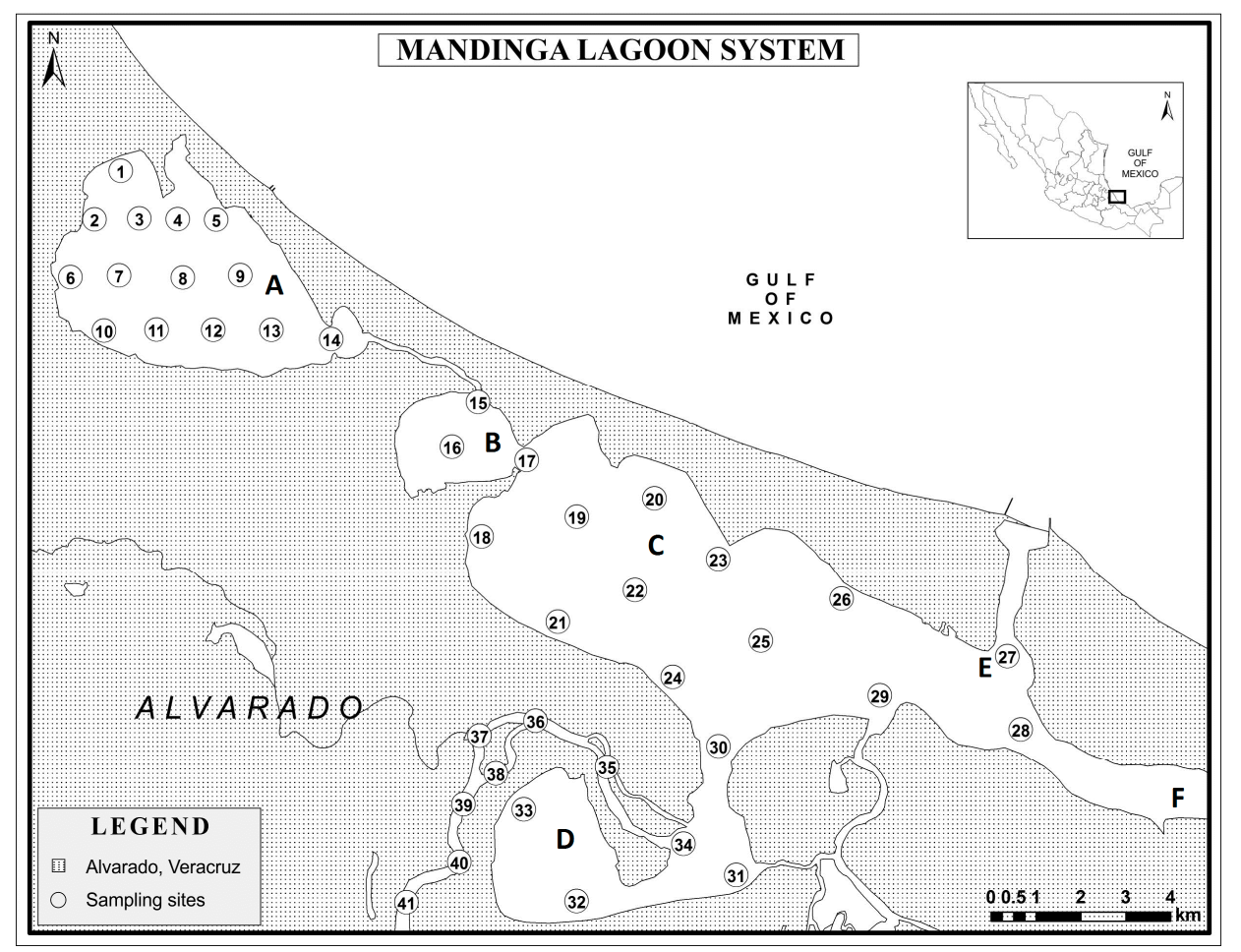

Figure 1. Sampling sites in the Alvarado lagoon system, Veracruz, Mexico. Lagoon bodies: A (Camaronera); B (Buen País); C (Alvarado); D (Tlalixcoyan); E (mouth of Alvarado); F (Papaloapan river).

Samples were collected at the sampling sites using a Van Veen crab-type dredge $\left(0.5 \mathrm{~L}, 126 \mathrm{~cm}^{2}\right.$, Eijkelkamp Soil \& Water, EM Giesbeek, The Netherlands ${ }^{\circledR}$ ) and stored in Ziploc ${ }^{\circledR}$ polyethylene bags for storage at temperatures from 4 to $5{ }^{\circ} \mathrm{C}$ while being transported to the laboratory, where they were frozen until treated and analyzed. The already frozen sediment samples were lyophilized in a Thermo Savant ModulyOD-114 kit for $72 \mathrm{~h}$ at $-49^{\circ} \mathrm{C}$ and at a vacuum pressure of $36 \times 10^{-3} \mathrm{mbar}$. After lyophilization, they were stored in sealed bags to be ground in a porcelain pistil mortar until a fine particle size was obtained. Finally, they were homogenized in a No. 30 sieve with an aperture of $595 \mu \mathrm{m}$. Samples were stored in a desiccator to avoid contact with ambient humidity.

\subsection{Analytical Procedures}

The material used in the development of this research was prepared according to the pesticide residue analysis protocol standardized [29]. The material was washed with phosphate-free neutral Extran $^{\circledR}$ soap for $24 \mathrm{~h}$, then rinsed with potable water, followed by distilled water (Milli-Q), finally washed with ethyl ether and acetone. To avoid cross-contamination of the samples, the purity of the ethyl ether used to wash the glassware was periodically evaluated using gas chromatography. 


\subsection{Microwave Extraction}

Extraction of pesticides from the sediment was performed with the CEM microwave equipment MARS 5 (CEM Corporation, Matthews, NC, USA). Solvents and reagents used in all analyses were reactive grade. The following were used: hexane (Backer) with a boiling temperature range of $40-50{ }^{\circ} \mathrm{C}$, sulfuric acid (Merck KGaA, Darmstadt, Germany) with a purity of $95-97 \%$, and sodium sulfate powder (J.T.Baker ${ }^{\circledR}$ ) previously activated and purified in a forced air oven model Riossa CF-102 at $650{ }^{\circ} \mathrm{C}$ for $24 \mathrm{~h}$.

The technique of Murphy [30] modified by Waliszewki [29] was used for the determination of the concentration of organochlorine pesticides. For this procedure, $10 \mathrm{~g}$ of lyophilized and ground sample was placed in a Teflon vessel with $20 \mathrm{~mL}$ of acetone and $20 \mathrm{~mL}$ of hexane as solvents. The microwave-assisted extraction was carried out for a period of $20 \mathrm{~min}$ at $110^{\circ} \mathrm{C}$ and a pressure of $200 \mathrm{PSI}$.

\subsection{Separation and Cleaning of Organochlorine Pesticides in Samples.}

The sample collected from the microwave extraction was placed in $250 \mathrm{~mL}$ flasks, this was cooled for $30 \mathrm{~min}$ and this solution was then filtered over a layer of anhydrous sodium sulfate $\left(\mathrm{Na}_{2} \mathrm{SO}_{4}\right)$ $8.0 \mathrm{~g}$ and washed with $10 \mathrm{~mL}$ of petroleum ether $\left(\mathrm{CH}_{3}\right)_{3} \mathrm{COCH}_{3}$. Subsequently, a final purification of the sample was performed with a Florisil ${ }^{\circledR}$ cartridge $\left(\mathrm{MgO}_{3} \mathrm{Si}\right)$ as an adsorbent for $60-100$ mesh chromatography (Sigma-Aldrich, Merck KGaA, Darmstadt, Germany). Finally, the obtained extract was concentrated with a rotoevaporator to a volume of $1 \mathrm{~mL}$ of purified sample at $45^{\circ} \mathrm{C}$ and stored in an amber vial (Reacti-vial, Pierce ${ }^{\circledR}$ ).

\subsection{Preparation of the Calibration Curve}

Quality control of the readings was performed on the chromatograph for each organochlorine pesticide analyzed. These were a total of 11 pesticides: $\alpha-\mathrm{HCH}$, lindane $(\gamma-\mathrm{HCH}), \beta-\mathrm{HCH}$, $\delta-\mathrm{HCH}$, heptachlor, aldrin, heptachlor epoxide, dieldrin, endrin, endrin aldehyde, and methoxiclor. By producing a linear regression of 5 points of the calibration curve, this procedure was performed. The reference standards and reference certificates used to make the calibration curve were ChemService, Inc., West Chester, PA, USA, a fortification test was also performed to ensure a recovery of $93 \%$.

\subsection{Quantification of Organochlorine Pesticides}

The equipment used for the quantification was a Thermo Electron Model Trace GC Ultra $115 \mathrm{~V}$ gas chromatograph (Thermo Fisher Scientific Inc., Paisley, UK) with electron capture detector. Pesticide separation was performed on a $14 \%$ cyanopropylphenyl polysiloxane chromatographic column from Thermo Fisher Scientific with dimensions of $30 \mathrm{~m} \times 0.32 \mathrm{~mm} \times 0.25 \mu \mathrm{m}$. Ultrapure nitrogen (Praxair, Mexico City, Mexico) was used as the entrainment gas at a flow rate of $2.5 \mathrm{~mL} / \mathrm{min}$. The operating temperatures were as follows: detector: $300^{\circ} \mathrm{C}$; injector: $250{ }^{\circ} \mathrm{C}$; column temperature from 160 to $280^{\circ} \mathrm{C}\left(4^{\circ} \mathrm{C} / \mathrm{min}\right)$. The injection volume was $1 \mu \mathrm{L}$ in splitless mode.

\section{Results and Discussion}

\subsection{Sediments as a Source of Pollutant Distribution}

The concentration of organochlorine pesticides analyzed at sampling sites $20-41$ had values below the detection limit of the equipment $\left(0.01 \mathrm{ng} \mathrm{g}^{-1}\right)$. Therefore, only the concentrations obtained in 20 sampling sites are reported, which included Sites 1-19 and 25. However, the presence of the 11 analyzed compounds was detected in all of the aforementioned sites (1-19 and 25). The authors of [11] also indicated that, in the Alvarado lagoon system, during the dry and rainy seasons, these compounds were detected in $100 \%$ of the samples analyzed. This indicates that there is a high risk for the aquatic biota that is in direct contact with the sediment in these sampling sites, particularly the molluscs, which act as a link between higher trophic levels like humans, which are indicative of pollution [31]. 
The presence of a higher concentration of organochlorine pesticides in sediments with respect to the concentrations was found in the analyzed water samples, which is why it is important to analyze the sediment matrix [32]. The presence of organochlorine compounds represents an environmental risk because of their bioaccumulation in the food chain and the alteration of aquatic ecosystems in both fresh and coastal waters [7,11]. Likewise, the contaminating effect of these compounds in productive activities such as fishing should be considered, and this effect is associated with the fact that the consumption of aquatic organisms with a certain concentration of these compounds represents a potential risk to public health (bioaccumulation and biomagnification) and can alter the quality of these ecosystems [7].

In coastal environments and according to their application, organochlorine pesticides must be closely related to what is established by Mexican legislation, since there are several prohibited and highly toxic compounds. Five pesticides (aldrin, dieldrin, endrin, mirex, and chlordecone) have been banned in Mexico, five are not marketed and are banned (chlordane, lindane, DDT, sulfluramide, and endosulfan), and finally six others have never been approved for use (heptachlor, HCB, toxaphene, pentachlorobenzene, and $\alpha-$, and $\beta-\mathrm{HCH}$ ) [7]. However, despite being banned, the presence of these compounds indicates their regular use, and degradation products of the original compounds are found in the environment [7].

\subsection{Hexachlorocyclohexane $(\mathrm{HCH})$}

Lindane was the only compound identified at Sampling Site 22 at a concentration of $40.51 \mathrm{ng} \mathrm{g}^{-1}$ and the same case was found for $\alpha-\mathrm{HCH}$ at Site 28 with an average concentration of $40.51 \mathrm{ng} \mathrm{g}^{-1}$. The remaining 20 sites had concentrations with the following minimum and maximum values, respectively: $\alpha-\mathrm{HCH}$ with 2.13 (Site 17) and 38.44 (Site 4); $\beta-\mathrm{HCH}$ with 2.56 (Site 16) and 42.11 (Site 2); lindane $(\gamma-\mathrm{HCH})$ with 1.45 (Site 15) and 34.20 (Site 13); $\delta-\mathrm{HCH}$ with 1.67 (Site 15) and $31.61 \mathrm{ng} \mathrm{g}^{-1}$ (Site 14) (Figure 2).

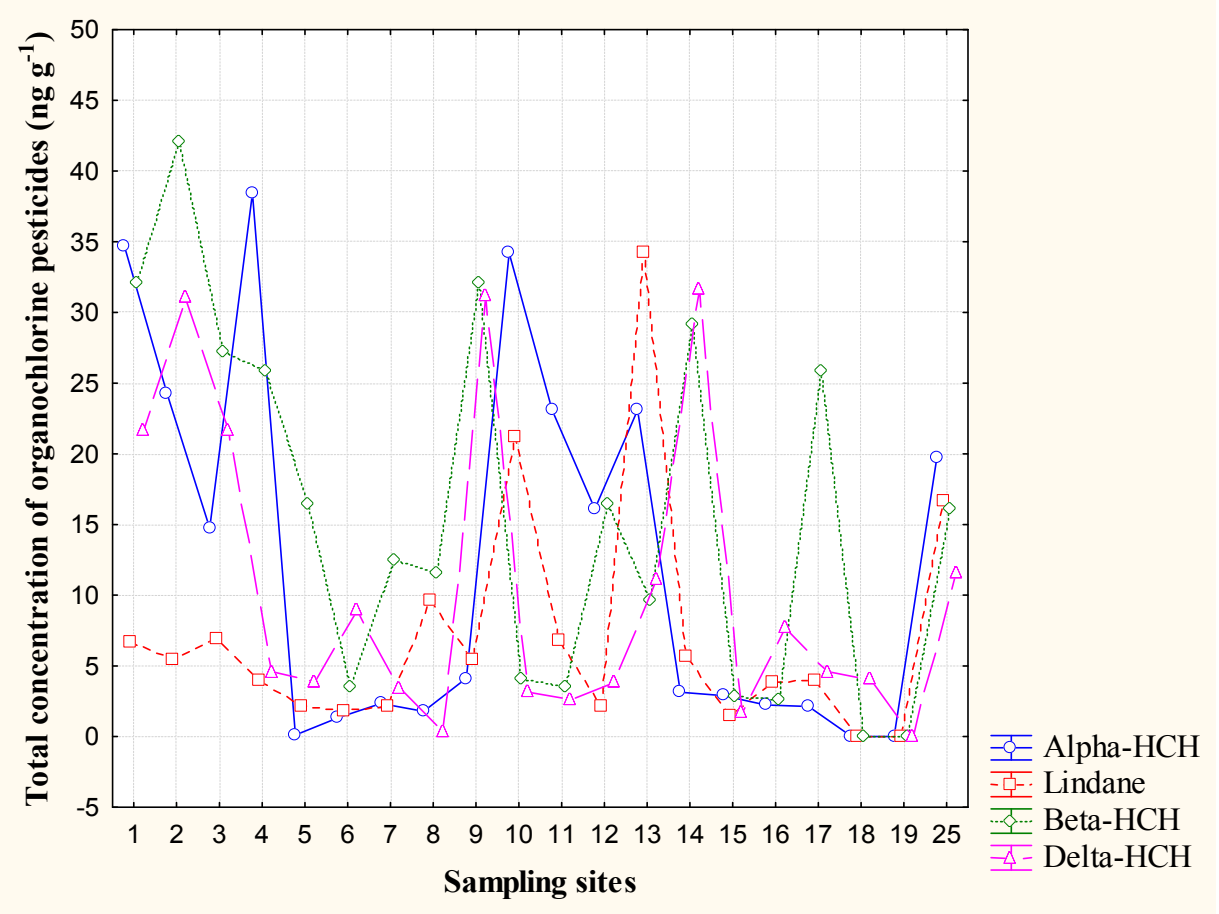

Figure 2. Total concentrations of the hexachlorocyclohexane $(\mathrm{HCH})$ group in sediment from the Alvarado lagoon, Veracruz, Mexico. 
The authors of [11] indicated that these sites are located in the central part of the Alvarado lagoon system, where the circulation of water bodies is minimal since these sites also have a low depth of approximately $1.5 \mathrm{~m}$. They also pointed out that this area of the lagoon presents silt-like sediment, which contributes to a greater accumulation of organic matter, because this type of soil, rich in humus, absorbs a greater quantity of pesticides than sandy soils.

Variations in the concentrations in Sites 18, 19, and 25 can also be associated with productive activities carried out in areas close to the lagoon system and, consequently, the contribution of effluents. Coinciding with Palmerín et al. [11], these sites were probably affected by the runoff from the agricultural fields of the nearby municipality of Tlalixcoyan, incorporating organic matter through the landslide of their soils. In addition, sites located near the mouths of the Acula and Papaloapan rivers directly receive sediment discharge from these effluents.

Research suggest that high concentrations of $\mathrm{HCH}$ are reportedly used extensively $[8,11]$. According to the information issued by CICOPLAFEST (Intersecretarial Commission for the Control of the Process and Use of Pesticides, Fertilizers and Toxic Substances), lindane $(\gamma-\mathrm{HCH})$ is comprised of approximately $10-15 \% \mathrm{HCH}$. This is authorized in Mexico for the control of plagues in crops such as oats (Avena sativa), barley (Hordeum vulgare), maize (Zea mays), sorghum (Sorghum bicolor), and wheat seeds (Triticum aestivum), for industrial use in pesticide-formulating plants, and for the control of some cattle pests such as mites and lice. The urban use for this pesticide is exclusively in health campaigns [8,33]. However, doing scientific research has become key due to the importance of this ecosystem with respect to its environmental quality and the intensive use of organochlorine pesticides in the area surrounding the lagoon system. Since research in this area is scarce, we can rely on those carried out by the authors of [34-36] and, more recently, the authors of [11].

Organochlorine pesticides, when they are incorporated into coastal ecosystems, are also subject to processes that involve the hydrodynamic behavior of the system-factors include the surface of the lagoon complex; topography, bathymetry, the speed and direction of the currents intervene in its dynamics, and the inflows and outflows of water into the lagoon system [37]. They result in variations in concentrations between the sampling sites and may also be related to circulation patterns in the Alvarado lagoon system, the depth and water exchange, the type of sediment, the circulation and accumulation (residence) of the water, the suspended particles, and the sediment between the lagoon bodies of the Alvarado system. The aforementioned can explain the detection of low concentrations of pesticides $\left(<0.01 \mathrm{ng} \mathrm{g}^{-1}\right)$ in Sampling Sites 20-24 and 26-41 and the circulation of the currents in the latter. This is directly due to the circulation pattern of the Alvarado lagoon system, whose mouth is the predominant entry point of marine water during the months of April and June, of fluvial and rain discharges in September during the rainy season, and apart from the impact of the winds present in the area during the north winds season [38].

In addition, one of the factors that influences the variability of these pollutants are the currents and the associated dilution phenomenon. Variations in the concentrations of organochlorines that depend on the sampling moment and the hydrodynamic factors existing in the lagoon have been reported. Regarding the above, the hydraulic operation of the system plays an important role in the dispersion of these pollutants [37].

The Agency for Toxic Substances and Disease Registry (ATSDR) also noted HCH's extensive use as an insecticide in fruit, vegetable, and forest plantations, in animals [39], and in storage spaces where these are maintained without a control of handling. The latter indicates that $\alpha$ and $\beta-\mathrm{HCH}$ have never been approved for use. Lindane $(\gamma-\mathrm{HCH})$ has not been marketed or prohibited [7]. ATSDR has classified $\gamma-\mathrm{HCH}$ as a pesticide for restricted use. It can be used by licensed and certified persons for its control and management [39].

Concentrations reported of the $\mathrm{HCH}$ isomers in this research in the Alvarado lagoon system were lower than those found in the state of Ondo, Nigeria, with the following concentrations: $\alpha$-HCH: not detected (ND): $<0.02 \mu \mathrm{g} \mathrm{g}{ }^{-1} ; 8.07 \pm 3.00 ; \beta-\mathrm{HCH}$ : ND: $10.91 \pm 6.66 \mu \mathrm{g} \mathrm{g}^{-1} ; \gamma-\mathrm{HCH}$ : ND: $9.08 \pm 0.02 \mu \mathrm{g} \mathrm{g}^{-1}$ [32]. Additionally, in the Densu River in Ghana, maximum sediment 
concentrations for $\gamma-\mathrm{HCH}\left(0.555 \pm 0.12 \mu \mathrm{g} \mathrm{kg}{ }^{-1}\right.$ and $\left.0.608 \pm 0.24 \mu \mathrm{gk}^{-1}\right)$ and $\delta-\mathrm{HCH}(0.140 \pm 0.05$ and $0.14 \pm 0.01 \mu \mathrm{g} \mathrm{kg}^{-1}$ ) have been reported. The variations in the distribution of the HCH isomers concentration were associated with the use and handling of the mixture of this compound in different localities. A greater contribution of $\gamma-\mathrm{HCH}$, compared to $\delta-\mathrm{HCH}$, was concluded due to its widespread use in the market as lindane $(\gamma-\mathrm{HCH})[40]$.

Lindane $(\gamma-\mathrm{HCH})$, even in low concentrations, represents a risk to public health, this compound is listed as a carcinogen of Group 1 by the International Agency for Research on Cancer (IARC) and the World Health Organization (WHO) [41]. ATSDR (2016a) also noted that IARC has classified all $\mathrm{HCH}$ isomers as possible carcinogens in humans [39].

\subsection{Cyclodienes (Endrin and Endrin Aldehyde, Aldrin and Dieldrin)}

The maximum concentration range of the cyclodiene family in the sediments of the Alvarado lagoon was as follows: aldrin: $46.05 \mathrm{ng} \mathrm{g}^{-1}$ (Site 3); endrin: $21.23 \mathrm{ng} \mathrm{g}^{-1}$ (Site 3); endrin aldehyde: $12.40 \mathrm{ng} \mathrm{g}^{-1}$ (Site 6); dieldrin: $22.13 \mathrm{ng} \mathrm{g}^{-1}$ (Site 3) (Table 1, Figure 3). The presence of a greater concentration of these pesticides at Sites 3 and 6 located in the lagoon body of Camaronera can be related with the reports of other research on its hydrodynamic (circulation within the system and discharge into the sea) and granulometric characteristics. This coincides with that reported by [38], who pointed out that, in the Camaronera lagoon, the fine clayey-silty sediments predominated and occur in shallow areas with less circulation. The above indicates that this area has lower hydrodynamic energy, which is why the fine fractions abounded. This is also related to the little change in the lagoon system, since its communication with the sea only occurs through the mouth of Alvarado (extension of $0.4 \mathrm{~km}$ ), due to the artificially constructed mouth in Camaronera, where approximately $0.003 \mathrm{~km}$ was closed [42], with the above, the replacement and water circulation in this lagoon body was reduced. The area of the mouth of the Alvarado lagoon is also influenced by marine currents by the Gulf of Mexico, as is the mouth of the Papaloapan River to the Buen País lagoon, where there is a higher proportion of silt [38].

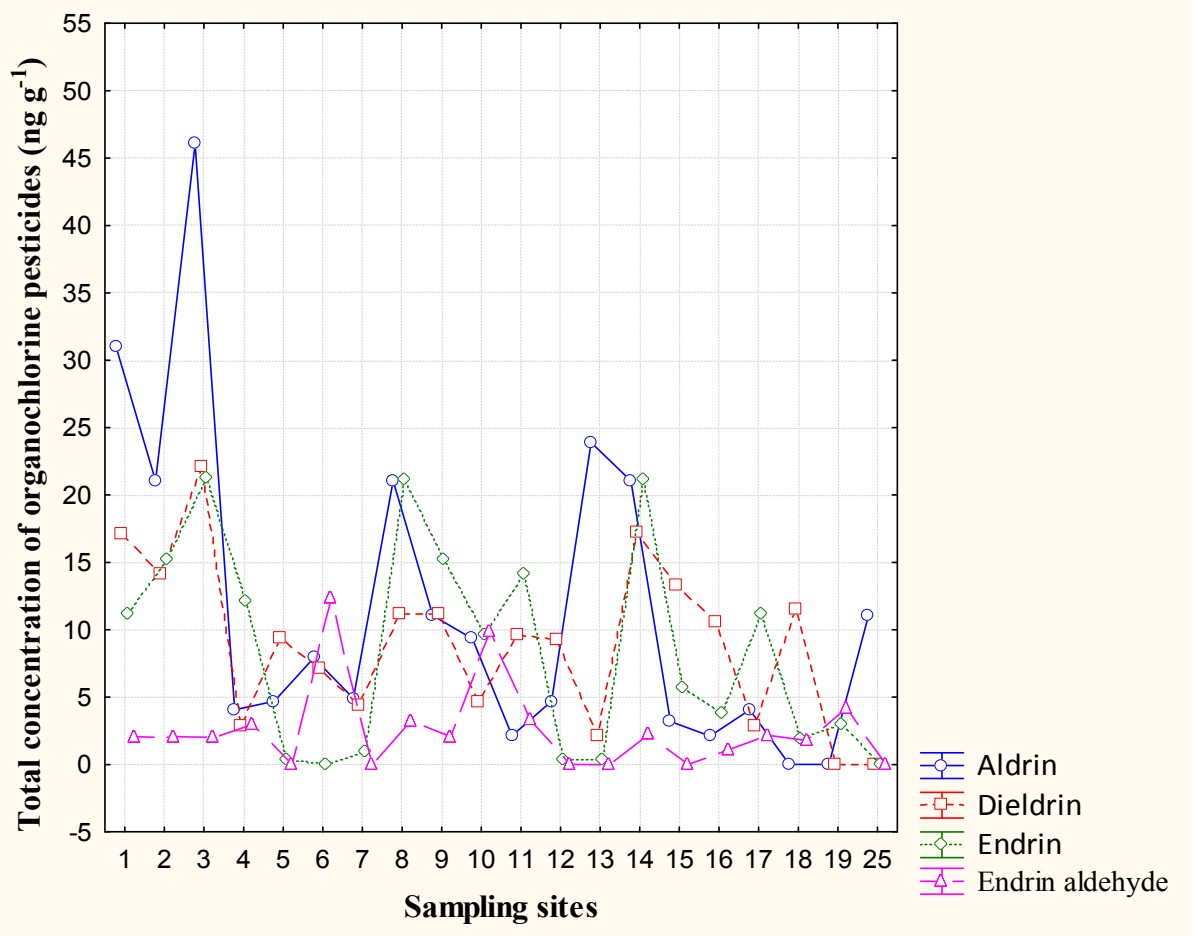

Figure 3. Total concentrations of the cyclodiene family in sediment of the Alvarado lagoon in Veracruz, Mexico. 
Table 1. Concentrations of organochlorine pesticides $\left(\mathrm{ng} \mathrm{g}^{-1}\right)$ in sediment of the Alvarado lagoon system in Veracruz, Mexico.

\begin{tabular}{ccccc}
\hline Compound & Minimum & Maximum & Mean & Standard Deviation \\
\hline alpha-HCH & 0.121 & 38.44 & 12.428 & 13.264 \\
gamma-HCH (Lindane) & 1.45 & 34.20 & 7.010 & 8.287 \\
beta-HCH & 2.56 & 42.11 & 15.683 & 12.737 \\
delta-HCH & 0.34 & 31.61 & 10.424 & 10.801 \\
Heptachlor & 1.98 & 24.11 & 8.621 & 8.000 \\
Aldrin & 2.11 & 46.05 & 11.667 & 12.088 \\
Heptachlor epoxide & 2.13 & 25.70 & 7.052 & 5.884 \\
Dieldrin & 2.18 & 22.13 & 9.041 & 6.051 \\
Endrin & 0.34 & 21.23 & 8.420 & 7.724 \\
Endrin aldehyde & $0.01 *$ & 12.40 & 2.581 & 3.224 \\
Methoxichlor & 1.13 & 29.40 & 5.650 & 6.561 \\
\hline
\end{tabular}

The type of sediment has a high influence on the dynamics of pesticides in a coastal lagoon [13]. Palmerín et al. [11] mentioned that the sand-silty sediments (Site 19 in this investigation) had a higher total concentration of organochlorine pesticides, with a concentration during the dry season increasing from 0.093 to $15,508 \mathrm{ng} \mathrm{g}^{-1}$. In the Alvarado lagoon where silts prevailed (43.34\%), clays in the Camaronera lagoon and an average of $43.22 \%$ of sand were obtained in Boca de Alvarado [38]. The latter may account for the lower concentration of organochlorine pesticides obtained in the present investigation, because this smaller accumulation of pesticides is attributed to sands Likewise, it has been reported that sedimentation and dilution are responsible for more than $50 \%$ of the decrease in concentrations of organochlorine pesticides in water [37].

Removing organochlorine compounds from the water column in an aquatic system is mainly done through processes such as precipitation and sedimentation [37]. In addition, during the rainy season in the Alvarado lagoon, it was reported by other researches like Palmerín et al. [11] that more fine sediments (silts and clays) were carried due to rain and river discharges, which caused their resuspension [38]. Therefore, this should be considered in the differences obtained in the sampling sites in the evaluation of the concentration of pesticides. Coinciding with the above, the authors of [11] reported that the minimum concentration of pesticides was detected in a sampling site located in the center of the lagoon, which was one of the sites with the greatest depth $(2 \mathrm{~m})$ [11]. Therefore, the hydrodynamic knowledge of a coastal ecosystem as a lagoon allows for a better understanding of the dynamic variations in the relationship between contamination by organochlorine pesticides and other parameters of water quality [37].

The characteristics of the Alvarado lagoon system and the contribution of pollutants to this system can be associated with the contribution of a greater concentration of pollutants in this area. Coinciding with the above, the authors of [36] reported the presence of the 11 compounds analyzed in this system and noted that these concentrations were higher than those obtained in the coastal lagoons of Carmen and Machona in Tabasco. Likewise, in Alvarado, they indicated that the concentrations of the pesticides analyzed, such as $\beta-\mathrm{HCH}$, aldrin, heptachlor, and heptachlor epoxide, were higher than the reported concentrations for coastal areas of Mexico, such as Chantuto-Panzacola lagoon in Chiapas, and the de Términos lagoon in Campeche (Table 2) [11].

The concentrations of diendrin in the present investigation were higher than those reported in the Alvarado lagoon by [34], they also indicated that this compound was detected in all the samples analyzed with concentrations ranging from 0.16 to $0.60 \mu \mathrm{g} \mathrm{kg}^{-1}\left(0.6 \mathrm{ng} \mathrm{g}^{-1}\right)$. Likewise, the concentrations obtained in the Alvarado lagoon system on this paper were also higher than those reported in Navachiste-Macapule lagoon in Sinaloa, Mexico, where maximum concentrations of $0.58 \mathrm{ng} \mathrm{g}^{-1}, 4.93 \pm 5.82 \mathrm{ng} \mathrm{g}^{-1}, 0.76 \pm 0.39$, and $1.13 \pm 0.80 \mathrm{ng} \mathrm{g}^{-1}$ were obtained for aldrin, endrin endrín aldehyde, and dieldrin, respectively [43]. In the case of Ondo state, the reported 
concentrations of these compounds were higher than those reported for the Navachiste lagoon; they are as follows: aldrin (not detected ND; $\left.6.55 \pm 0.02 \mu \mathrm{g} \mathrm{g}^{-1}\right)$; dieldrin $\left(0.01 \pm 0.01,7.62 \pm 5.72 \mu \mathrm{g} \mathrm{g}^{-1}\right)$; endrin (ND: $21.28 \pm 3.17 \mu \mathrm{g} \mathrm{g}^{-1}$ ) [32]. Furthermore, regarding benthic sediment from Agboyi Creek, Lagos, Nigeria, high concentrations were reported: aldrin $\left(43.6 \pm 2.1 \mathrm{ng} \mathrm{g}^{-1}\right)$; endrin $(8139.5 \pm 2.3)$; endrin aldehyde $(536.2 \pm 7.4)$; dieldrin $\left(38.9 \pm 7.5 \mathrm{ng} \mathrm{g}^{-1}\right)$ [44]. The high concentrations of endrin, followed by dieldrin, endrin aldehyde, and aldrin indicate recent application. In addition, these maximum concentrations can be associated with the rainy season due to runoff from agricultural fields [43].

Table 2. Concentrations of organochlorine pesticides evaluated in sediment from the Alvarado lagoon system in Veracruz, Mexico.

\begin{tabular}{|c|c|c|c|}
\hline Compound & $\begin{array}{l}\text { Díaz-González and } \\
\text { Rueda-Quintana }\left(\mathrm{ng} \mathrm{g}^{-1}\right) \text { [34] }\end{array}$ & Botello et al. $\left(\operatorname{ng~g}^{-1}\right)$ [35] & Palmerín et al. $\left(\right.$ ng g $\left.^{-1}\right)[11]^{*}$ \\
\hline alpha-HCH & 2.61 & $0.47 \pm 0.29$ & 3.49 \\
\hline$\gamma$-HCH (Lindane) & 2.73 & $0.85 \pm 0.63$ & 4.784 \\
\hline beta- $\mathrm{HCH}$ & 2.08 & $1.86 \pm 0.60$ & 28.49 \\
\hline$\delta-\mathrm{HCH}$ & NA & NA & 17.29 \\
\hline Heptachlor & 2.91 & $3.91 \pm 2.21$ & 46 \\
\hline Aldrin & 6.61 & $2.11 \pm 1.66$ & 82.36 \\
\hline Heptachlor epoxide & 2.17 & $0.86 \pm 0.45$ & 52.32 \\
\hline Dieldrin & ND & $2.05 \pm 1.08$ & ND \\
\hline Endrin & 7.95 & $7.82 \pm 4.77$ & 4.42 \\
\hline Endrin aldehyde & 1.92 & 1.77 & 18.51 \\
\hline Methoxichlor & NA & NA & NA \\
\hline
\end{tabular}

Despite variations in concentrations among various investigations, the detection of endrin compounds suggests its continued use, despite its prohibition by government laws [43]. In Mexico, however, the Federal Commission for the protection against Sanitary Risk (COFEPRIS) is the only federal agency that issues these types of regulations on the use of pesticides. The ATSDR recommended consuming no more than $0.002 \mathrm{mg} \mathrm{L}^{-1}$ endrin in water over an entire lifetime and, in the case of ambient waters, recommended a maximum level of $0.001 \mathrm{mg} \mathrm{L}^{-1}$ to protect the health of human beings [45].

\subsection{Methoxichlor and Heptachlor}

The maximum value of methoxychlor obtained in sediment of the Alvarado lagoon was 29.40 at Site 19 (Figure 4), followed by heptachlor with 24.1 at Site 3, and heptachlor epoxide with $25.79 \mathrm{ng} \mathrm{g}^{-1}$ at Site 11. Regarding the above, Sites 3 and 4 located in the Camaronera lagoon also showed higher concentrations of other pesticides determined in the present investigation. Coinciding with the above, the authors of [11] also indicated that, in the Alvarado lagoon, the sediment collected in rainfall presented high concentrations of heptachlor epoxide. These concentrations significantly exceeded the levels established by the Threshold Effects Level (TEL) and the Probable Effects Level (PEL), so the benthic organisms could be subject to adverse biological effects [11]. The toxicological effect of these compounds in aquatic biota is related to their mobilization in the ecosystem, coinciding with the above. Other researchers [37] indicated that organochlorine pesticides when removed from the water column do not suffer any type of degradation because of its persistence, and if pelagic aquatic organisms do not absorb these, their final destination is their accumulation at the bottom of the aquatic bodies, thus impacting benthic bodies [37].

However, the concentrations of these pesticides obtained in Alvarado were lower than those reported in Lagos, Nigeria, with maximum concentrations of $146.7 \pm 8.2 \mathrm{ng} \mathrm{g}^{-1}$ for methoxychlor, $125.6 \pm 8.5 \mathrm{ng} \mathrm{g}^{-1}$ for heptachlor, and $403.6 \pm 9.3 \mathrm{ng} \mathrm{g}^{-1}$ for heptachlor epoxide [44]. The above concentrations for heptachlor are high, considering that ATSDR reported $0.01 \mathrm{mg} \mathrm{L}^{-1}$ as the limit 
for most crops. In the case of food, the limit reported in edible seafood was $0.3 \mathrm{mg} \mathrm{L}^{-1}$ [46]. It should be noted that there are few previously reported investigations in the Alvarado lagoon system, which makes it difficult to determine whether there is a continuous contribution of these compounds. The compounds heptachlor and heptachlor epoxide, like other organochlorines, including methoxychlor, adhere strongly to soil and sediment, evaporate slowly in the air and do not readily dissolve in water. The heptachlor epoxide dissolves readily in water opposite to heptachlor and evaporates slowly therefrom. Therefore, heptachlor epoxide degrades very slowly in the environment and can remain in soil and water for many years [46].

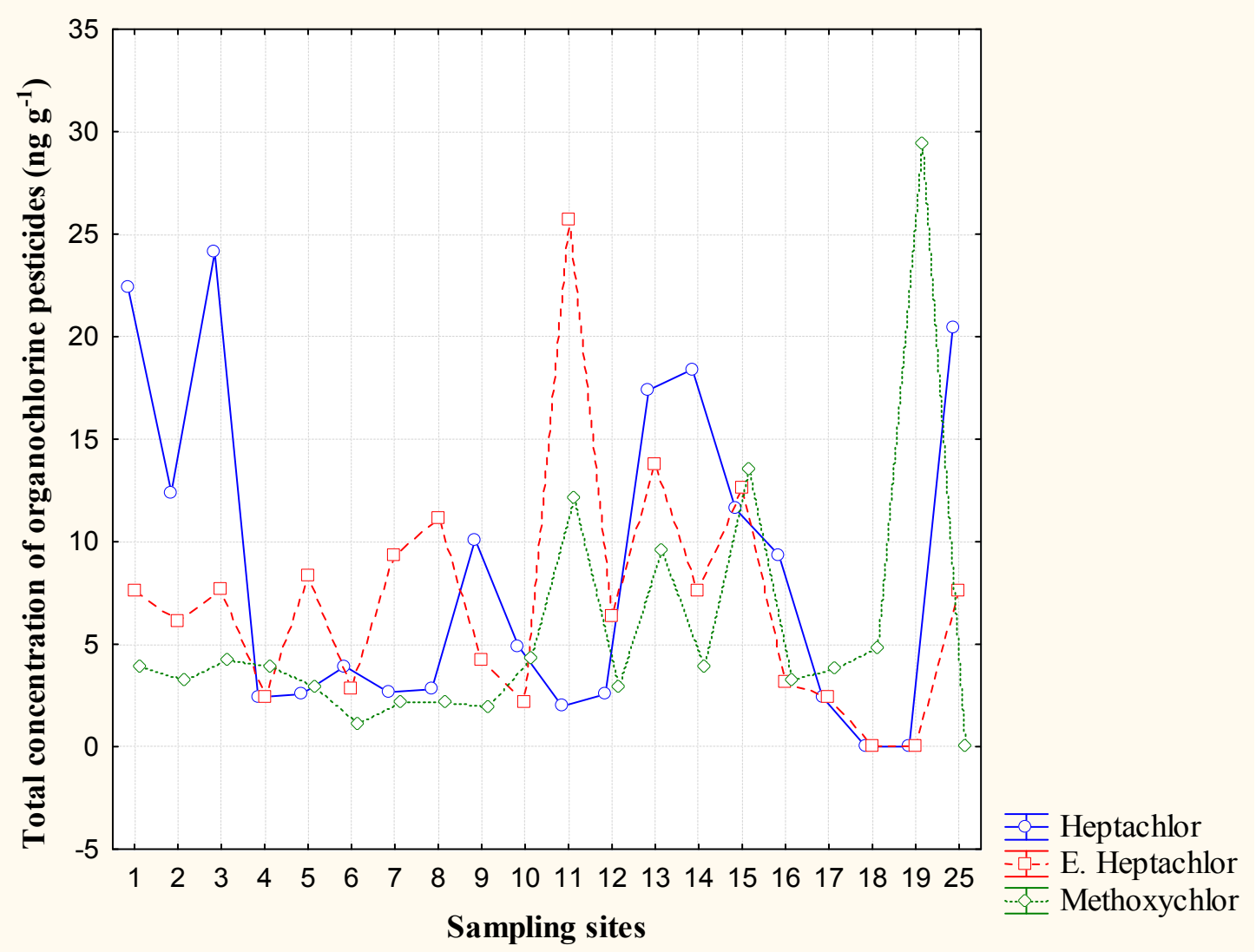

Figure 4. Concentrations of methoxichlor and heptachlor in sediment of the Alvarado lagoon in Veracruz, Mexico.

The detection of methoxychlor and heptachlor, as well as other organochlorines (endrin and DDT) suggests its continued use, despite their prohibition by governmental laws [43]. It must be considered in the case of methoxychlor that most of it enters the environment when applied to agricultural crops, forests, and livestock. The degradation of this compound is slow in environmental matrices (air, water, and soil). Due to the effect of sunlight and microorganisms, this degradation can take a period of several months. Additionally, some degradation products of methoxychlor may be as damaging as the parent compound. Among toxicological effects, the presence of high levels of this compound in animals produced tremors and convulsions and affected fertility [47].

Studies conducted obtained a higher concentration of methoxychlor $\left(12.70 \pm 15.20 \mathrm{ng} \mathrm{g}^{-1}\right)$ compared to heptachlor $\left(5.95 \pm 6.72 \mathrm{ng} \mathrm{g}^{-1}\right)$ and heptachlor epoxide $\left(0.50 \pm 0.14 \mathrm{ng} \mathrm{g}^{-1}\right)$ [43]. The authors remarked that the high concentration of the first compound in the sediments suggests constant use in the regions that influence the lagoon system. According to the ATSDR, this is due to the fact that methoxychlor released into air is eventually deposited in soil, where it firmly adheres 
to particles. In addition, its aqueous solubility is very low $\left(0.056\left(\mathrm{mg} \mathrm{L}^{-1}\right.\right.$ at $\left.20^{\circ} \mathrm{C}\right)$, in contrast to heptachlor epoxide with $0.275 \mathrm{mg} \mathrm{L}^{-1}[8,48]$. Therefore, this compound is adhered to sediments and deposited in the bottom of bodies of water. It is important to mention that the amount of methoxychlor that is recommendation by ATSDR contained in drinking water is $0.04 \mathrm{mg} \mathrm{L}^{-1}$ [47].

In addition to the persistence of these compounds in the environment, its accumulation in living beings and therefore its toxicity must be considered. ATSDR noted that heptachlor and heptachlor epoxide accumulate in fish and livestock, whereas in human beings, heptachlor epoxide can be stored in body fat. It has been shown that the latter can be detected in the body fat of a person 3 years after exposure to this substance. Additionally, heptachlor epoxide is more toxic than heptachlor in laboratory animals [46]. With respect to the long-term effect on health and due to the heptachlor toxicity and its metabolite, the International Agency for Research on Cancer (IARC) has classified both compounds as a possible carcinogenic in humans [46].

\section{Conclusions}

Concentrations of organochlorine pesticides in the analyzed sampling sites show their influence on the dynamics of the Alvarado lagoon system. These compounds are exported to the coastal zone and finally deposited in open sea.

This research highlights the need for constant monitoring in sediments of the lagoon system and hydrological basins of influence that are located in different regions of Mexico. Sediments are the habitat of different aquatic organisms, such as crustaceans and bivalve molluscs that get contaminated and therefore, when consumed by people, could represent an element of risk to public health.

Compounds highly toxic to public health of the group of organochlorine pesticides, such as hexachlorocyclohexanes, cyclodiene, methoxychlor, and heptachlor were identified in this study. The concentrations found indicate their illegal use in Mexico, despite being banned internationally.

Efficient regulation in the use and management of insecticides and the promotion of environmentally friendly compounds in agricultural and livestock activities are required.

It is necessary to reflect on including the sediment matrix in the environmental legislation of Mexico to establish the maximum permissible limits in aquatic ecosystems. Considering that these sediments are the habitat of important species of aquatic organisms of national and international consumption.

Acknowledgments: To the Tecnológico Nacional de México and to the Academic Group of the PRODEP Aquaculture and Fisheries Sciences.

Author Contributions: All authors significantly contributed to the article.

Conflicts of Interest: The authors declare no conflict of interest.

\section{References}

1. She, J.; Holden, A.; Sharp, M.; Tañer, M.; Williams-Derry, C.; Hooper, K. Polybrominated Diphenyl Ethers (PBDEs) and Polychlorinated Biphenyls (PCBs) in Breast Milk from the Pacific Northwest. Chemosphere 2007, 67, S307-S317. [CrossRef] [PubMed]

2. Grimalt, J.; Fernández, P.; Berdie, L.; Vilanova, R.M.; Catalán, J.; Psenner, R.; Hofer, R.; Appleby, P.G.; Rosseland, B.O.; Lien, L.; et al. Selective trapping of organochlorine compounds in mountain lakes of temperate areas. Environ. Sci. Technol. 2001, 35, 2690-2697. [CrossRef] [PubMed]

3. Arbeli, Z. Biodegradación de compuestos orgánicos persistentes (COP): I. El Caso de los Bifenilos Policlorados (PCB). Acta Biol. Colomb. 2009, 14, 57-88.

4. Lupi, L.; Bedmar, F.; Wunderlin, D.A.; Miglioranza, K.S.B. Organochlorine pesticides in agricultural soils and associated biota. Environ. Earth Sci. 2016, 75, 519. [CrossRef]

5. García-Gutiérrez, C.; Rodríguez-Meza, G.D. Problemática y riesgo ambiental por el uso de plaguicidas en Sinaloa. Ra Ximhai 2012, 8, 1-10. 
6. Waliszewski, S.M.; Caba, M.; Goméz-Arroyo, S.; Villalobos-Pietrini, R.; Mártinez, A.; Valencia-Quintana, R.; Lozano-Flores, M.E.; Regalado-Torres, M.A. Niveles de plaguicidas organoclorados en habitantes de México. Rev. Int. Contam. Ambient. 2013, 29, 121-131.

7. Arellano-Aguilar, O.; Betancourt-Lozano, M.; Aguilar-Zárate, G.; Ponce de León-Hill, C. Agrochemical loading in drains and rivers and its connection with pollution in coastal lagoons of the Mexican Pacific. Environ. Monit. Assess. 2017, 189, 270. [CrossRef] [PubMed]

8. Leyva-Morales, J.B.; Valdez-Torres, J.B.; Bastidas-Bastidas, P.J.; Angulo-Escalante, M.A.; Sarmiento-Sánchez, J.I.; Barraza-Lobo, A.L.; Olmeda-Rubio, C.; Chaidez-Quiroz, C. Monitoring of pesticides residues in northwestern Mexico rivers. Acta Univ. 2017, 27, 45-54. [CrossRef]

9. Castañeda-Chávez, M.R.; Lango-Reynoso, F.; Landeros-Sánchez, C. DDT in Crassostrea virginica (Gmelin, 1791) of Coastal Lagoons in the Gulf of Mexico. J. Agric. Sci. 2011, 3, 183-193. [CrossRef]

10. Lango-Reynoso, F.; Castañeda-Chávez, M.R.; Landeros-Sánchez, C.; Galavíz-Villa, I.; Navarrete-Rodríguez, G.; Soto-Estrada, $\mathrm{A} . \mathrm{Cd}, \mathrm{Cu}, \mathrm{Hg}$ and $\mathrm{Pb}$, and organochlorine pesticides in commercially important benthic organisms from coastal lagoons along the SW Gulf of Mexico. Agric. Sci. 2013, 1, 63-80. [CrossRef]

11. Palmerín, R.C.; Ponce, V.G.; Botello, A.V. Evaluación de plaguicidas organoclorados en sedimentos y organismos filtradores de la laguna de Alvarado, Veracruz, México. In Golfo de México. Contaminación e Impacto Ambiental: Diagnóstico y Tendencias, 3rd ed.; Botello, A.V., Rendón von Osten, J., Benítez, J., Gold-Bouchot, G., Eds.; La Universidad Nacional Autónoma de México (UNAM): de la Ciudad de México, Mexico, 2014; pp. 285-308, ISBN 978-607-7887-71-3.

12. Navarrete-Rodríguez, G.; Landeros-Sánchez, C.; Soto-Estrada, A.; Castañeda-Chávez, M.R.; Lango-Reynoso, F.; Pérez-Vázquez, A.; Nikolskii-Gavrilov, I. Endosulfan: Its Isomers and Metabolites in Commercially Aquatic Organisms from the Gulf of Mexico and the Caribbean. J. Agric. Sci. 2016, 8, 8-24. [CrossRef]

13. Ramírez-Elías, M.A.; Córdova-Quiroz, A.V.; Cerón-Bretón, J.G.; Cerón-Bretón, R.M.; Rendón-von Osten, J.; Hipólito-Cortés, S.J. Dichloro-Diphenyl-Trichloroethane (DDT) and Endosulfan in Sediments of Sabancuy Lagoon, Campeche, Mexico. Open J. Ecol. 2016, 6, 22-31. [CrossRef]

14. Albert, L.A.; Benítez, J.A. Impacto ambiental de los plaguicidas en los ecosistemas costeros. In Golfo de México Contaminación e Impacto Ambiental: Diagnóstico y Tendencias, 2nd ed.; Botello, A.V., Rendón von Osten, J., Gold Bouchot, G., Hernández, C.A., Eds.; Univ. Nal. Autón. de México, Instituto Nacional de Ecología: de Campeche, Mexico, 2005; pp. 157-176, ISBN 968-5722-37-4.

15. Albert, L.A. Los plaguicidas y sus riesgos para el ambiente. In Golfo de México Contaminación e Impacto Ambiental: Diagnóstico y Tendencias, 3rd ed.; Botello, A.V., Rendón von Osten, J., Benítez, J., Gold-Bouchot, G., Eds.; La Universidad Nacional Autónoma de México (UNAM): de la Ciudad de México, Mexico, 2014; pp. 183-212, ISBN 978-607-7887-71-3.

16. Leyva-Cardoso, D.O.; Ponce-Vélez, G.; Botello, A.V.; Díaz-González, G. Persistent organochlorine pesticides in coastal sediments from Petacalco Bay, Guerrero, México. Bull. Environ. Contam. Toxicol. 2003, 71, 1244-1251. [CrossRef] [PubMed]

17. Aguilar, C.A.; Montalvo, C.; Rodríguez, L.; Cerón, J.G.; Cerón, R.M. American oyster (Crassostrea virginica) and sediments as a coastal zone pollution monitor by heavy metals. Int. J. Environ. Sci. Technol. 2012, 9, 579-586. [CrossRef]

18. Villanueva, F.S.; Páez-Osuna, F. Contaminantes críticos: Metales. In Golfo de México, Contaminación e Impacto Ambiental: Diagnostico y Tendencias; Botello, A.V., Rojas-Galaviz, J.L., Benítez, J., Zárate-Lomelí, D., Eds.; EPOMEX Serie Científica 5; Universidad Autónoma de Campeche: México D.F., Mexico, 1995; pp. 681-710.

19. Carvalho, F.P.; Gonzalez-Farias, F.; Villeneuve, J.P.; Cattini, C.; Hernandez-Garza, M.; Mee, L.D. Distribution, fate and effects of pesticide residues in tropical coastal lagoons of Northwestern Mexico. Environ. Toxicol. 2002, 23, 1257-1270.

20. Gonzalez-Farías, F.; Hernández-Garza, M.; Díaz-González, G. Organic carbon and pesticide pollution in a tropical coastal lagoon-estuarine system in Northwest Mexico. Int. J. Environ. Pollut. 2006, 26, 234-253. [CrossRef]

21. USGS (U.S. Geological Survey). Pesticides in Stream Sediment and Aquatic Biota. Current Understanding of Distribution and Major Influences. Pesticide National Synthesis Project. 2017. Available online: https:/ / water.usgs.gov/nawqa/pnsp/pubs/fs09200/fs09200.pdf (accessed on 28 May 2017). 
22. Portilla-Ochoa, E. Ficha Informativa de los Humedales de Ramsar (FIR). Nombre del Sitio Ramsar: Sistema Lagunar Alvarado. 2003. Available online: http://ramsar.conanp.gob.mx/docs/sitios/FIR_RAMSAR/ Veracruz/Sistema_Lagunar_Alvarado/Sistema\%20Lagunar\%20Alvarado.pdf (accessed on 30 July 2017).

23. Carta Nacional Pesquera. Ecosistemas Lagunares Costeros. Diario Oficial de la Federación. Available online: http:/ / www.conapesca.sagarpa.gob.mx/wb/cona/cona_parte_4_ (accessed on 29 July 2017).

24. Castañeda-Chávez, M.R.; Sedas, V.P.; Orrantia-Borunda, E. Influence of water temperature and salinity on seasonal occurrences of Vibrio cholerae and enteric bacteria in oyster-producing areas of Veracruz, México. Mar. Pollut. Bull. 2005, 50, 1641-1648. [CrossRef] [PubMed]

25. Bello, P.J.; Cervantes, A.M.; Gómez, L.; Magaña, V.; Graizbord, B.; Hipólito, R.V. Sitio piloto Río Papaloapan-Laguna de Alvarado. In Adaptabilidad a los Impactos del Cambio Climático en los Humedales Costeros del Golfo de Mexico; Buenfil-Friedman, J., Ed.; Secretaría de Medio Ambiente y Recursos Naturales (Semarnat): Ciudad de México, Mexico, 2009; Volume 2, pp. 435-456.

26. Portilla-Ochoa, E.; Sánchez-Hernández, A.I.; Ortega-Argueta, A.; Juárez-Eusebio, A.; Escobar-López, H.E.; Gutiérrez-García, R.; Montejo-Díaz, J.E.; Cortina-Julio, B.E.; Garza-Garza, S.; García-Hernández, C. Establecimiento de Unidades de Gestión Ambiental en el Humedal de Alvarado, Veracruz, México: Bases para su Ordenamiento Ecológico y Social; Informe Técnico Semestral; Universidad Veracruzana: Jalapa, Mexico, 2003; p. 45.

27. Vázquez-Lule, A.D.; Rodríguez-Zúñiga, M.T.; Ramírez-García, P. Caracterización del Sitio de Manglar Sistema Lagunar de Alvarado Veracruz, en Comisión Nacional para el Conocimiento y Uso de la Biodiversidad (CONABIO). Sitios de Manglar con Relevancia Biológica y con Necesidades de Rehabilitación Ecológica; CONABIO. Available online: http:/ / www.biodiversidad.gob.mx/ecosistemas/manglares/pdf/caracterizacion/GM53_ Sistema_Lagunar_de_Alvarado_veracruz_caracterizacion.pdf (accessed on 13 August 2017).

28. CONABIO (Comisión Nacional para el Conocimiento y Uso de la Biodiversidad). Ficha Técnica para la Evaluación de los Sitios Prioritarios para la Conservación de los Ambientes Costeros y Oceánicos de México: Sistema Lagunar de Alvarado. Available online: http://www.conabio.gob.mx/gap/images/1/1b/60_ Sistema_Lagunar_Alvarado.pdf (accessed on 13 August 2017).

29. Waliszewski, S.M.; Mójica, G.X.; Infanzón, R.M.; Barradas, D.C.M.; Carvajal, Z.O. Uso del ácido sulfúrico en las determinaciones de plaguicidas organoclorados. I. Calidad químico-analítica de la preparación de grasas por el ácido sulfúrico Concentrado. Rev. Int. Contam. Ambient. 2008, 24, 33-38.

30. Murphy, P.G. Sulfuric acid for the cleanup of animal tissues for analysis of acid-stable chlorinated hydrocarbon residues. J. Assoc. Off. Anal. Chem. 1972, 55, 1360-1362. [PubMed]

31. Mamta; Rao, R.J.; Wani, K.A. Concentration of organochlorine and organophosphorus pesticides in different molluscs from Tighra Reservoir, Gwalior, India. Bull. Environ. Contam. Toxicol. 2015, 95, 332-339.

32. Okoya, A.A.; Ogunfowokan, A.O.; Asubiojo, O.I.; Torto, N. Organochlorine Pesticide Residues in Sediments and Waters from Cocoa Producing Areas of Ondo State, Southwestern Nigeria. ISRN Soil Sci. 2013, 2013, 131647. [CrossRef]

33. CICOPLAFEST. Catálogo Oficial de Plaguicidas. Mexico: Secretaría de Medio Ambiente y Recursos Naturales (Semarnap)/Secretaría de Comercio y Fomento Industrial (Secofi)/SAGAR/Secretaría de Salud (SSA); COFEPRIS: Ciudad de México, Mexico, 2004; p. 483.

34. Rosales-Hoz, M.T.L.; Alvarez-León, R. Niveles actuales de hidrocarburos organoclorados en sedimentos de lagunas costeras del golfo de México. Anales del Centro de Ciencias del Mar y Limnología. In Proceedings of the VI Congreso Nacional de Oceanografía, Ensenada, Mexico, 10-13 April 1978.

35. Botello, A.V.; Díaz, G.; Rueda, L.; Villanueva, S.F. Organochlorine compounds in oysters and sediments from coastal lagoons of the Gulf of Mexico. Bull. Environ. Contam. Toxicol. 1994, 53, 238-245. [CrossRef] [PubMed]

36. Díaz-González, G.; Rueda Quintana, L. Niveles de concentraciones de plaguicidas organoclorados en las lagunas del Carmen, Machona y Alvarado. In Golfo de México, Contaminación e Impacto Ambiental: Diagnóstico y Tendencias; Botello, A.V., Rojas-Galavíz, J.L., Benítez, J.A., Zárate-Lomelí, Y.D., Eds.; EPOMEX Serie Científica, 5; Universidad Autónoma de Campeche: Campeche, Mexico, 1996; pp. 177-185.

37. Betancourt, J.M.; Ramírez-Triana, G. Estudio de los procesos relacionados con la presencia de plaguicidas organoclorados en la ciénaga grande de Santa Marta. Bol. Invest. Mar. Cost. 2005, 34, 121-139. [CrossRef]

38. Calva Benítez, L.G.; Torres-Alvarado, M.R. Textura de sedimentos y carbono orgánico en el sistema costero lagunar Alvarado, Veracruz. Contactos 2011, 81, 11-16. 
39. ATSDR (Agency for Toxic Substances and Disease Registry). Resumen de Salud Pública. Hexacloro-ciclohexano. Agencia para Sustancias Tóxicas y el Registro de Enfermedades. Atlanta, GA: Departamento de Salud y Servicios Humanos de los EE.UU., Servicio de Salud Pública. Available online: https: / /www.atsdr.cdc.gov/es/phs/es_phs43.pdf (accessed on 29 August 2017).

40. Kuranchie-Mensahm, H.; Manukure-Atiemo, S.; Naa-Dedei-Palm, L.M.; Blankson-Arthur, S.; Osei-Tutu, A.; Fosu, P. Determination of organochlorine pesticide residue in sediment and water from the Densu river basin, Ghana. Chemosphere 2012, 86, 286-292. [CrossRef] [PubMed]

41. Loomis, D.; Mattpck, H.; Straif, K.; Zavadil, A. Carcinogenicity of lindane, DDT, and 2, 4-dichlorophenoxyacetic acid. Lancet Oncol. 2015, 16, 891-892. [CrossRef]

42. Castañeda, L.O.y.F.C.E. Los ecosistemas costeros del estado de Veracruz. Gobierno del Estado de Veracruz; Secretaría de Desarrollo Agropecuario, Forestal y Pesquero: Tabasco, Mexico, 1995; p. 144.

43. Montes, A.M.; Gonzalez-Farias, F.A.; Botello, A.V. Pollution by organochlorine pesticides in Navachiste-Macapule, Sinaloa, Mexico. Environ. Monit. Assess. 2012, 184, 1359-1369. [CrossRef] [PubMed]

44. Williams, A.B. Residue analysis of organochlorine pesticides in water and sediments from Agboyi Creek, Lagos. Afr. J. Environ. Sci. Technol. 2013, 7, 267-273. [CrossRef]

45. ATSDR. Resumen de Salud Pública. Endrina. Agencia para Sustancias Tóxicas y el Registro de Enfermedades. Atlanta, GA: Departamento de Salud y Servicios Humanos de los EE.UU, Servicio de Salud Pública. 2016. Available online: https:/ / www.atsdr.cdc.gov / es/toxfaqs/es_tfacts89.html (accessed on 29 August 2017).

46. ATSDR. Resumen de Salud Pública. Heptacloro. Agencia para Sustancias Tóxicas y el Registro de Enfermedades. Atlanta, GA: Departamento de Salud y Servicios Humanos de los EE.UU., Servicio de Salud Pública. 2016. Available online: https://www.atsdr.cdc.gov/es/phs/es_phs12.html (accessed on 27 August 2017).

47. ATSDR. Resumen de Salud Pública. Metoxicloro. Agencia para Sustancias Tóxicas y el Registro de Enfermedades. Atlanta, GA: Departamento de Salud y Servicios Humanos de los EE.UU., Servicio de Salud Pública. 2016. Available online: https:/ /www.atsdr.cdc.gov/es/toxfaqs/es_tfacts47.html (accessed on 27 August 2017).

48. ATSDR. Toxicological Profile for Heptachlor and Heptachlor Epoxide; U.S. Department of Health and Human Services, Public Health Service, Agency for Toxic Substances and Disease Registry: Atlanta, GA, USA, 2007; p. 158.

(C) 2018 by the authors. Licensee MDPI, Basel, Switzerland. This article is an open access article distributed under the terms and conditions of the Creative Commons Attribution (CC BY) license (http://creativecommons.org/licenses/by/4.0/). 